\title{
In vitro growth of the microsporidian Heterosporis saurida in the eel kidney EK-1 cell line
}

\author{
Mona Saleh ${ }^{1}$, Gokhlesh Kumar ${ }^{1}$, Abdel-Azeem Abdel-Baki ${ }^{2,3}$, \\ Mansour El-Matbouli ${ }^{1}$, Saleh Al-Quraishy ${ }^{2, *}$ \\ ${ }^{1}$ Clinical Division of Fish Medicine, University of Veterinary Medicine, Vienna, Austria \\ ${ }^{2}$ Zoology Department, College of Science, King Saud University, Riyadh, Saudi Arabia \\ ${ }^{3}$ Zoology Department, Faculty of Science, Beni-Suef University, Beni-Suef, Egypt
}

\begin{abstract}
Heterosporis saurida is an intracellular microsporidian that infects lizardfish Saurida undosquamis. Although some attempts have been introduced to clarify microsporidian host-pathogen interactions, development of novel strategies to combat fish diseases is still needed. Here we present an in vitro cultivation model for fish microsporidia based on an eel kidney cell line (EK-1), which is susceptible to infection by $H$. saurida. Spores were isolated from infected lizardfish and used to inoculate EK-1 cells. H. saurida were propagated in the eel kidney EK-1 cell line and detected by immunofluorescence. Developmental stages of $H$. saurida were seen in EK-1 cells by transmission electron microscopy. Identity of the parasite was confirmed by partial sequencing of the 16S rDNA gene. Our cell culture model provides a valuable means to explore molecular and immunological events and will facilitate development of effective treatment strategies.
\end{abstract}

KEY WORDS: Fish $\cdot$ Microsporidia $\cdot$ Heterosporis saurida $\cdot$ Disease $\cdot$ Cell culture $\cdot$ EK-1 cell line Resale or republication not permitted without written consent of the publisher

\section{INTRODUCTION}

Microsporidia are obligate intracellular parasites of all major animal groups, including fish. Microsporidian infections in fish are deleterious and endanger the lives of the hosts. Outbreaks can reach epizootic levels, especially under hatchery conditions, which favor transmission (Lom \& Dykova 1992, Schmahl \& Benini 1998). High mortality rates caused by Heterosporis saurida have contributed to declines in production of economically important fish, and subsequent financial losses in aquaculture industries (Al-Quraishy et al. 2012). Microsporidia were originally identified as fungi, but they were reclassified as protozoans by the end of the 19th century, an assignation that was accepted for over $100 \mathrm{yr}$ until molecular techniques and phylogenetic analyses placed microsporidia back into the Fungi (Nageli 1857, Pasteur 1870, Hirt et al. 1999, Keeling et al. 2000, Keeling \& Fast 2002).
Although microsporidia are obligate intracellular pathogens, they have an extracellular infective spore phase of development. This spore contains a hollow polar filament, which distinguishes microsporidia from all other organisms and plays a crucial role in host cell invasion. The spore extrudes the filament, through which it then injects its sporoplasm and nucleus into the cytoplasm of the host cell. Intracellular proliferation follows, characterized by the developmental stages of merogony and sporogony (Monaghan et al. 2009). The phylum Microsporidia comprises over 1200 species in nearly 150 genera (Wittner 1999, Franzen \& Müller 2001). Of these, 18 genera have members known to infect fish, and include Glugea, Loma, Heterosporis, and Nucelospora, which cause severe disease in economically important fish (Lom \& Nilsen 2003, Sanders et al. 2012). Several Heterosporis species have been reported to infect fish: $H$. anguillarum in cul- 
tured eels in Japan (Hoshina 1951), H. schuberti in cultured ornamental cichlids and loricarid catfish from Germany (Lom et al. 1989), and H. finki in cultured angelfish Pterophyllum scalare from France (Michel et al. 1989). An undetermined species of Heterosporis was reported from cultured bettas Betta splendens in Thailand (Lom et al. 1993). Since 2000, Heterosporis has been confirmed in yellow perch Perca flavescens in the USA (Miller 2009). Most recently, $H$. saurida has been described from lizardfish Saurida undosquamis in the Arabian Gulf, Saudi Arabia (Al-Quraishy et al. 2012). These Heterosporis species, in particular, cause significant pathogenic effects on the host and hence have negative economic consequences in the fish trade (AlQuraishy et al. 2012).

Interest in in vitro propagation of certain microsporidia has intensified recently because several microsporidia are found to have low host specificity (Rinder et al. 2000, Sutherland et al. 2000, Lores et al. 2003, Coyle et al. 2004, Kumar et al. 2013), and some genera have been identified as opportunistic pathogens of humans, especially patients with acquired immune deficiency syndrome (AIDS; Didier 2005). Microsporidia that parasitize humans have also been reported in domestic animals, which may represent reservoir hosts (Breitenmoser et al. 1999, Mathis et al. 1999, Rinder et al. 2000). The fact that microsporidia have been observed in fishes and can be cultured in mammalian cell lines, e.g. Heterosporosis sp. in the rabbit kidney epithelial cell line RK-13, supports the hypothesis that mammals may be natural reservoir hosts of fish microsporidia (Lores et al. 2003, Kumar et al. 2013).

Although cell and tissue cultures are essential tools for the propagation and study of obligate intracellular pathogens such as microsporidia, research is hindered by a lack of suitable cell cultures for propagation and study of fish microsporidia. In vitro cultivation of parasitic microsporidia not only provides information on the development of the parasite but also enables new approaches for disease control. In vitro propagation will also help to identify specific proteins that may enhance the invasive properties of the parasite and subsequently lead to the development of monoclonal antibodies that will aid in neutralizing parasitic invasion. Moreover, evaluation of functional antibodies and cell-mediated defensive systems against the parasites and screening of drugs in order to identify potential therapeutic agents can only be made in a cost-effective manner using in vitro culture (Visvesvara \& Garcia 2002). Large numbers of parasites at specific stages can be produced in cultures, which allows time-series molecular studies to be performed (Didier et al. 1994, 1996, Deplazes et al. 1996, Hollister et al. 1996, Croppo et al. 1997, Mathis et al. 1997, Franzen \& Müller 2001, del Aguila et al. 2001). Moreover, continuous culture over long periods of time may cause attenuation of strains, which potentially leads to development of vaccines (Visvesvara \& Garcia 2002).

In this study, we present a cell culture model for Heterosporis saurida in eel kidney epithelial cells (EK-1). Development of this in vitro approach was essential for our planned research into the control of H. saurida using small interfering RNA (siRNA) technology, and will facilitate immunological and cellpathogen interaction studies.

\section{MATERIALS AND METHODS}

\section{Collection of Heterosporis saurida spores}

Lizardfish were collected from 2 localities in Saudi Arabia: a fish market in Riyadh, and from fishermen in Al-Gezan on the Red Sea. Infection was determined by the occurrence of numerous cysts in the abdominal cavity, skeletal muscles, and the mesenteric tissues (Al-Quraishy et al. 2012). Using 2 sterile scalpels, cysts were carefully opened and spores were released into a Petri dish and collected in $2 \mathrm{ml}$ microcentrifuge tubes. Released spores were then kept in distilled water at $4^{\circ} \mathrm{C}$ until used for PCR and in vitro studies.

\section{Cell line and growth conditions}

Eel kidney epithelial cells (EK-1; Chen et al. 1982) were grown at $26^{\circ} \mathrm{C}$ and maintained in L-15 (Leibovitz) medium with L-glutamine (Sigma Aldrich), and $10 \%$ fetal bovine serum (FBS, Invitrogen). Penicillin and streptomycin (Sigma Aldrich) were added at $100 \mathrm{IU} \mathrm{ml}^{-1}$ and $100 \mu \mathrm{g} \mathrm{ml}^{-1}$, respectively.

\section{Preparation of spores}

Microsporidian spores were treated with $10000 \mathrm{U}$ $\mathrm{ml}^{-1}$ penicillin and $10000 \mu \mathrm{g} \mathrm{m} \mathrm{m}^{-1}$ streptomycin in $\mathrm{L}-15$ medium for $2 \mathrm{~h}$ at $37^{\circ} \mathrm{C}$ to inactivate bacteria. Spore pellets were washed twice with L-15 medium, resuspended in L-15 medium and counted using a hemocytometer to achieve a concentration from $1 \times$ $10^{5}$ to $1 \times 10^{7}$ spores $\mathrm{ml}^{-1}$. 


\section{In vitro infection of EK-1 cells with Heterosporis saurida spores}

EK-1 cells were sub-cultured and seeded in 24well plates in duplicate. Six wells were infected with different spore concentrations $\left(1 \times 10^{5}, 1 \times 10^{6}\right.$, and $1 \times 10^{7}$ spores $\mathrm{ml}^{-1}$ ). The remaining wells received no spores and were used as no-spore controls. L-15 medium supplemented with $10 \%$ FBS was added to the cells, and $24 \mathrm{~h}$ after seeding, $100 \mu \mathrm{l}$ of the spore suspensions were added to each cell line monolayer. At $2 \mathrm{~d}$ post-infection (p.i.), the medium was removed from each well and the well was rinsed 3 times with fresh medium. The medium was replaced twice a week and the cell cultures were observed every day under an inverted microscope. The whole procedure was repeated 3 times to assess in vitro growth of spores.

\section{Re-infection of EK-1 cells}

At 3 wk p.i., monolayers were trypsinized, harvested, and centrifuged. Pellets were re-suspended in L-15 medium and used to infect new cultures of EK-1 cells, maintained as described previously.

\section{Production of Heterosporis saurida spores in EK-1 cells}

EK-1 cells were grown in two 24 -well plates, and $1 \times 10^{7}$ spores of $H$. saurida were added to each of the wells. Six wells on each plate received no spores and were used as no-spore controls. The cells were predominantly epithelial-like and were grown at $26^{\circ} \mathrm{C}$ in L-15 supplemented as described above. At $2 \mathrm{~d}$ p.i., cells were washed 3 times with phosphatebuffered saline (PBS) to remove non-attached spores from the wells. Cells were lysed to release the spores, centrifuged, then washed with medium supplemented with $10 \%$ FBS. Pelleted spores were re-suspended in PBS. Spores were counted in duplicates from 4 wells of infected cells using a hemocytometer, and numbers of spores were recorded every week for $3 \mathrm{wk}$.

\section{Transmission electron microscopy (TEM)}

Cultures were interrupted at $12,24,48,72 \mathrm{~h}$, and 1 wk p.i. EK-1 cells were washed with serum-free L-15 medium, trypsinized, and harvested in $10 \mathrm{ml}$ sterile glass tubes. Cell pellets were washed twice with PBS, pH 7.2, and fixed in $5 \%$ glutaraldehyde (Sigma Aldrich) for $2 \mathrm{~h}$ at $4^{\circ} \mathrm{C}$. Cells were washed twice with $0.2 \mathrm{M}$ phosphate buffer $\mathrm{pH} 7.4$, then incubated overnight in the same buffer at $4^{\circ} \mathrm{C}$, then postfixed in $1 \%$ osmium tetroxide (Sigma Aldrich) at $4^{\circ} \mathrm{C}$ for $2 \mathrm{~h}$. After several steps of dehydration, the cells were embedded in Epon, and semi-thin sections were cut and then stained with toluidine blue (Sigma Aldrich). The sections were contrasted with uranyl acetate and lead citrate (Sigma Aldrich) and then examined using an electron microscope (Zeiss EM109).

\section{Immunofluorescence assay for detection of Heterosporis saurida in EK-1 cells}

Inverted phase contrast with fluorescence attachment and confocal microscopes were used to monitor living and fixed cultures. Living cultures were observed daily by phase contrast microscopy. Cell cultures were fixed in cold acetone/ethanol (1:1) for 10 min at $4^{\circ} \mathrm{C}$, air dried, and washed 3 times with PBS. Non-specific binding was blocked with $1 \%$ bovine serum albumin (Sigma Aldrich) for $30 \mathrm{~min}$. After washing for 3 times for 5 min with PBS, the fixed cells were then incubated with rabbit antiserum containing polyclonal antibodies against microsporidia (Medicago; $1: 50$ dilution) for $1 \mathrm{~h}$ at $37^{\circ} \mathrm{C}$. The cells were washed 4 times, and then incubated with fluorescein isothiocyanate (FITC)-conjugated goat anti-rabbit IgG (1:400) for $45 \mathrm{~min}$ at $37^{\circ} \mathrm{C}$ (Sigma Aldrich). One microliter of propidium iodide $\left(1 \mathrm{mg} \mathrm{ml}^{-1}\right.$; Sigma Aldrich) was added to counterstain the nuclei. The control cells were incubated and covered with the diluted stain for 1 to $5 \mathrm{~min}$. The wells were then washed 3 times with PBS for 10 min each and mounted with mounting medium (Invitrogen).

\section{PCR detection of Heterosporis saurida in infected cells}

At 1 wk p.i, cells were harvested and washed with PBS, and then DNA was extracted using a QIAamp DNA Mini Kit (Qiagen). PCR primers HG4F (5'-GCG GCT TAA TTT GAC TCA AC-3') and HG4R (5'-TCT CCT TGG TCC GTG TTT CAA-3') were used according to Gatehouse \& Malone (1998). PCR amplicons were cloned into the pDrive cloning vector (Qiagen) and sequenced (LGC Genomics). An NCBI-BLAST similarity search was performed. 


\section{RESULTS}

Prior to being added to EK-1 cells, spores were ovoid and phase-bright, and cells had the ordinary phase-contrast appearance of epithelial cells in culture (Fig. 1A). The highest infection rate in EK-1 cells was obtained when $1 \times 10^{7} \mathrm{ml}^{-1}$ of Heterosporis saurida was used, whereas lower infections were observed with $1 \times 10^{6}$ and $1 \times 10^{5} \mathrm{ml}^{-1} \mathrm{H}$. saurida. The majority of EK-1 cells were infected at $24 \mathrm{~h}$ p.i.

Successful infection of Heterosporis saurida was clearly visible by phase contrast microscopy in EK1 cultures 48 h p.i. (Fig. 1B). Spindle-shaped structures, meronts, sporonts, and mature spores of $H$. saurida spores were observed in the cytoplasm. Cytopathic effects were evident within $48 \mathrm{~h}$, with respect to controls, viz. hypertrophy of the nucleus and cytoplasm.

Transmission electron microscopy showed a variety of microsporidian developmental stages. Spores were observed in the host cell cytoplasm, and all stages were present near the nucleus from $12 \mathrm{~h}$ p.i., which was evidence for replication of the parasite in EK-1 cells (Fig. 2). Developmental stages were seen in the host
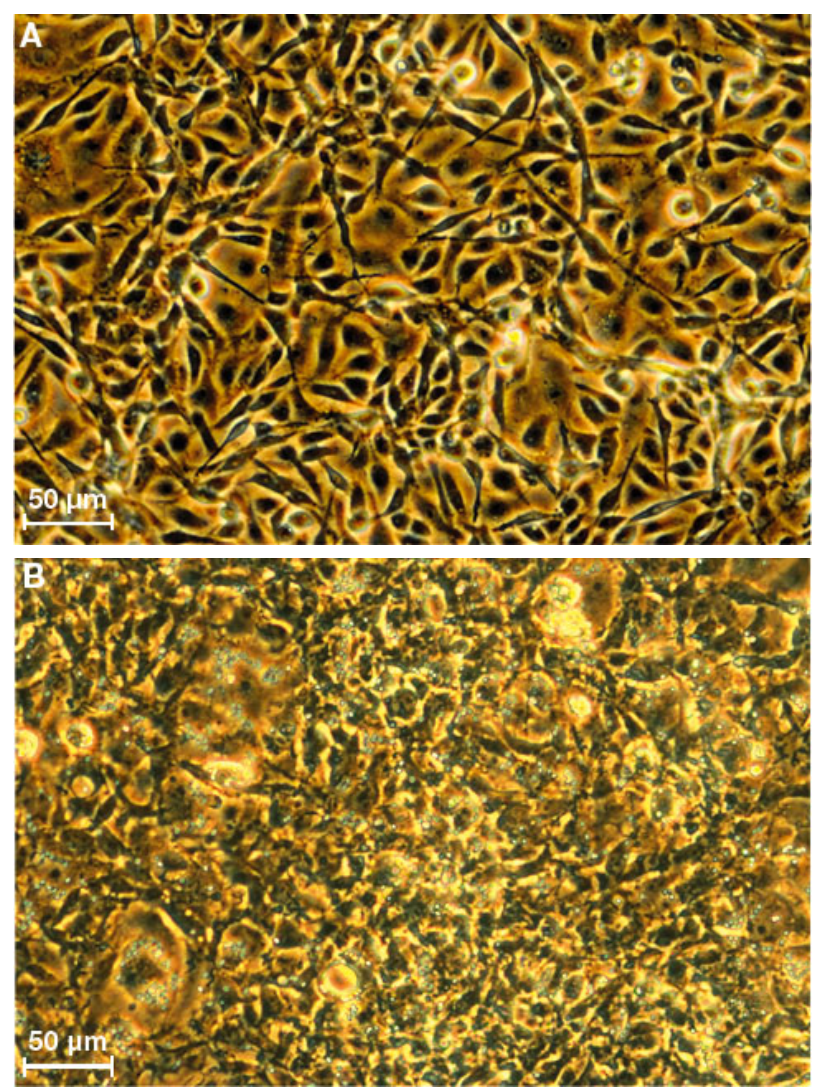

Fig. 1. Phase contrast images showing eel kidney epithelial cell line EK-1. (A) Non-infected control and (B) infected with Heterosporis saurida cell cytoplasm. Sporogonial stages were monosporoblastic or disporoblastic. The spores had a clear, thin, electron-dense exospore and a thick, electron-lucent endospore (Fig. 2B). Weekly spore counts showed that the number of Heterosporis saurida increased with time (Fig. 3). With prolonged incubation time, destruction of the cell monolayer occurred and cell-free areas appeared. At 3 wk p.i., cells detached and lysed, and $H$. saurida spores were released into the medium.
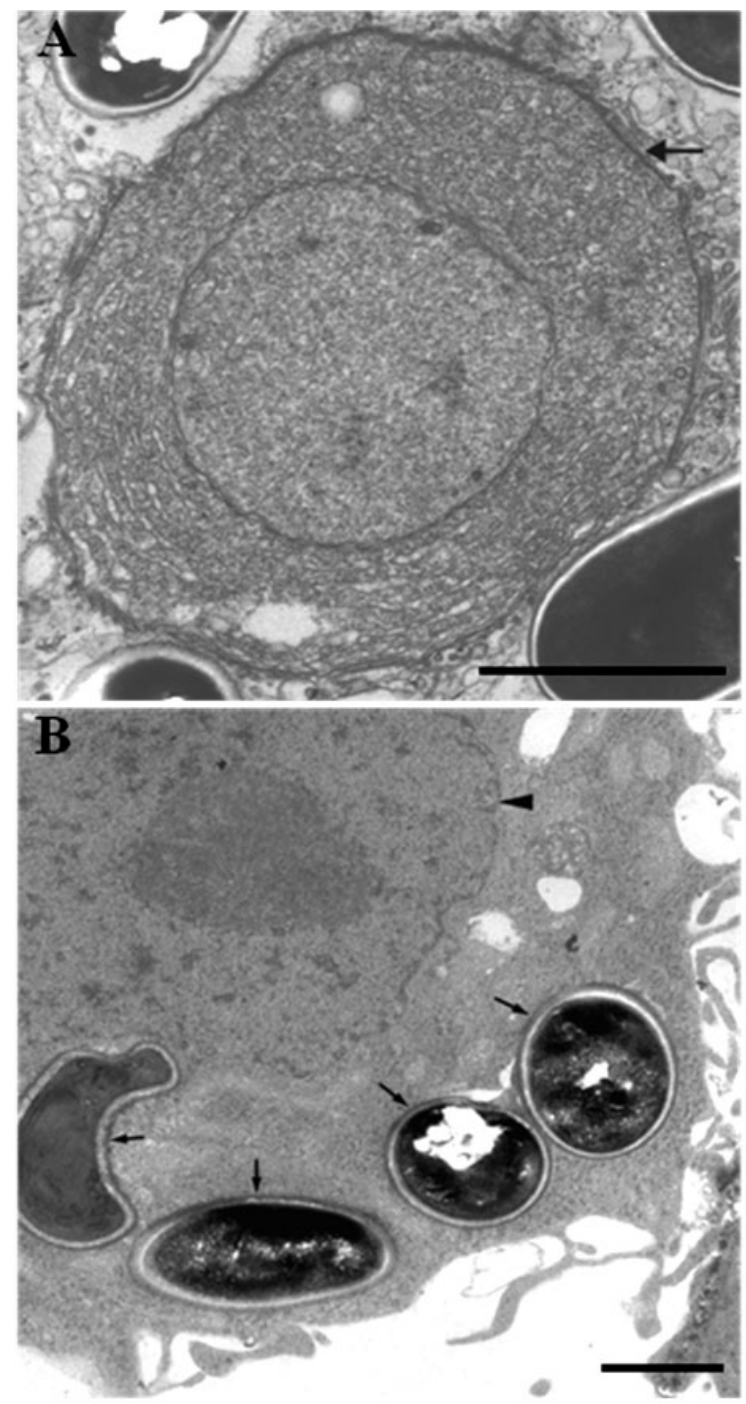

Fig. 2. Heterosporis saurida. Transmission electron microscope images showing developmental stages in eel kidney epithelial cells. (A) Infected cell showing meront (arrow) with endoplasmic reticulum and ribosomes bound by a plasma membrane in direct contact with cell cytoplasm. Scale bar $=0.5 \mu \mathrm{m}$. (B) Detail of infected cell showing sporonts, which were elongated and oval in shape with dense cytoplasm and no discernible internal structures. Mature spores (arrows) showed that the spore wall consisted of a dense exospore and a lucent layer endospore; arrowhead indicates the host cell nucleus. Scale bar $=1 \mu \mathrm{m}$ 
We observed the complete microsporidian life cycle, with successful infection of Heterosporis saurida in EK-1 cells and evident signs of infection seen 2 d p.i. Spindle-shaped structures, meronts, sporonts, and mature spores of $H$. saurida were evident in the cytoplasm. Production of new spores was observed by $72 \mathrm{~h}$ at $26^{\circ} \mathrm{C}$; the $H$. saurida-infected cell suspension successfully re-infected new EK-1 cell cultures. Strong fluorescence was observed upon addition of the antimicrosporidia polyclonal antibody to $H$. saurida spores in EK-1 cells. The parasite was observed in the host cell cytoplasm near the nucleus (Figs. 4 \& 5).

A $1100 \mathrm{bp}$ PCR fragment of Heterosporis saurida from both spores and EK-1 infected cells was amplified (Fig. 6), and the NCBI BLAST search demonstrated that the amplicons had $100 \%$ similarity with H. saurida (JF745533).
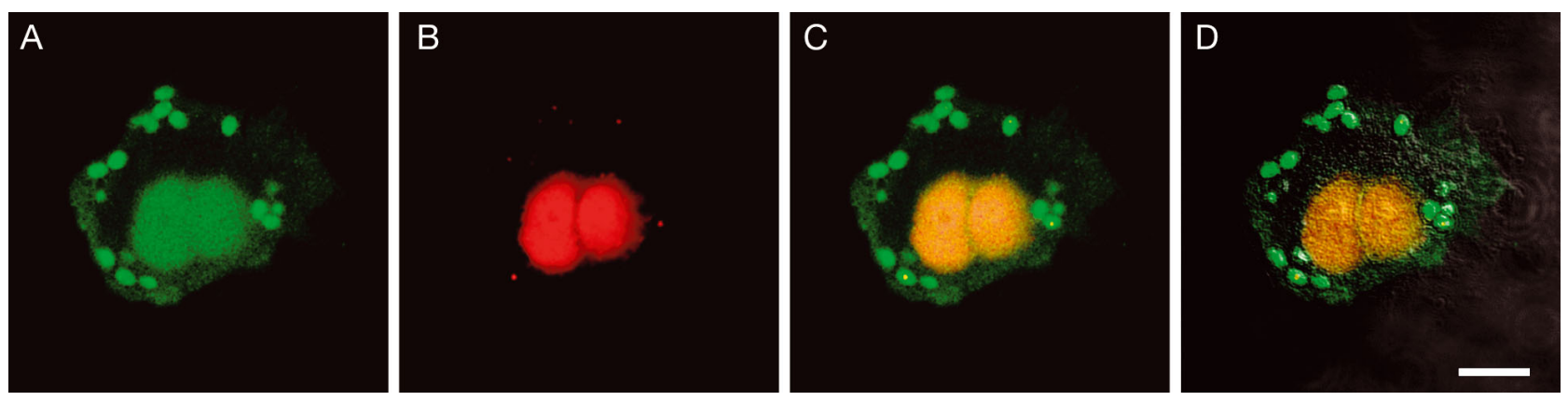

Fig. 4. Immunofluorescence assay of Heterosporis saurida in EK-1: confocal microscopy view collected from (A) green, (B) red, and $(\mathrm{C}, \mathrm{D})$ merged channels. H. saurida spores (in green) are stained with fluorescein isothiocyanate (FITC)-conjugated with goat anti-rabbit IgG after an incubation step with polyclonal antibodies raised against microsporidia. The nuclei (in red) are

counterstained with propidium iodide. Scale bar $=1 \mu \mathrm{m}$
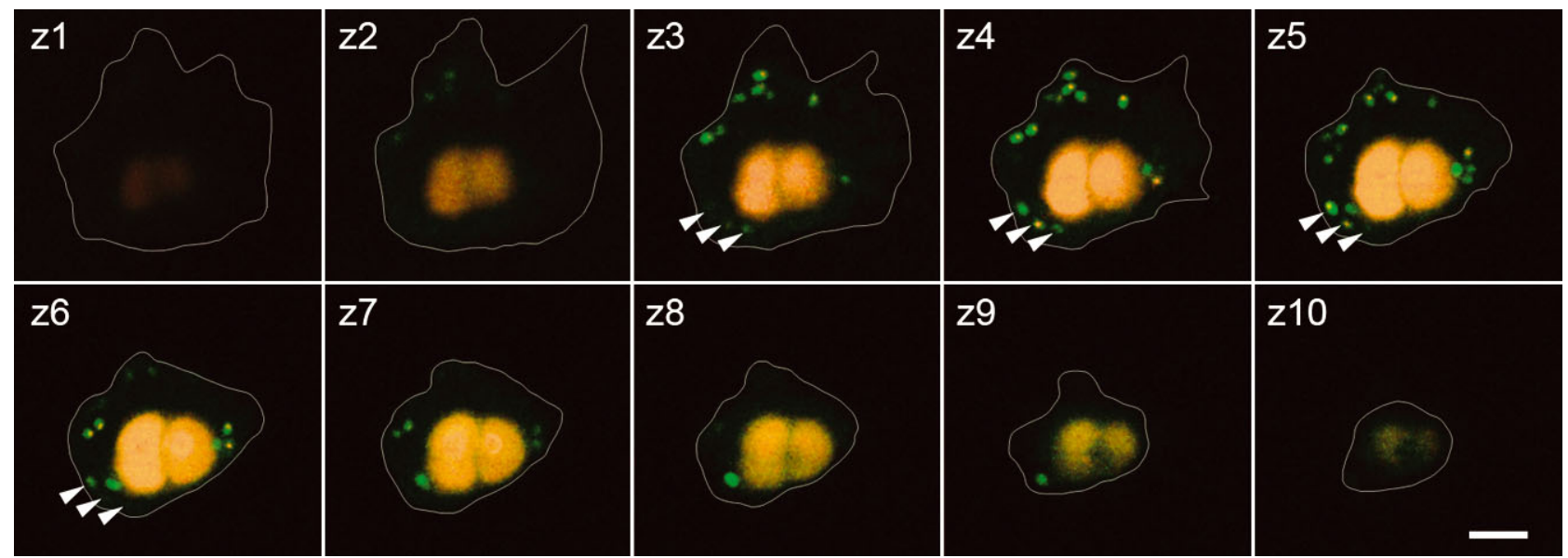

Fig. 5. Heterosporis saurida. $z$-axis series of confocal images showing the spores (white arrowheads) in the host cell cytoplasm near the nucleus. Scale bar $=1 \mu \mathrm{m}$ 


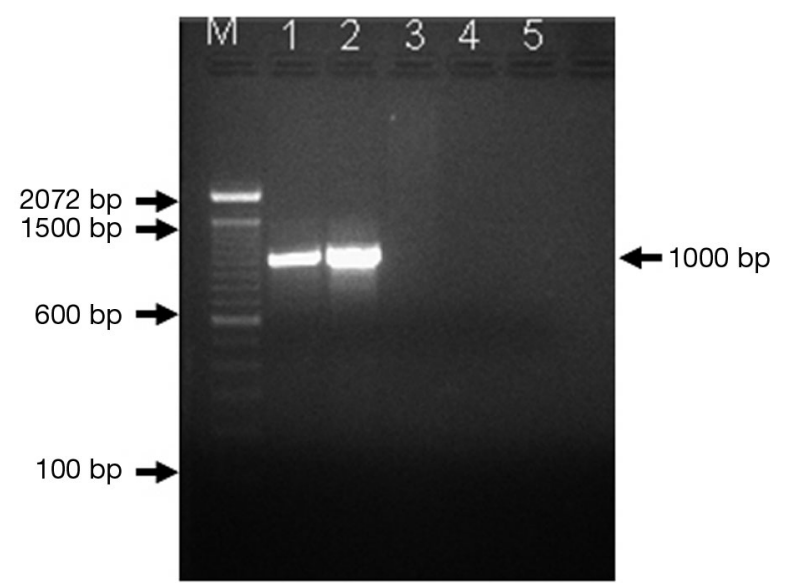

Fig. 6. Heterosporis saurida. Agarose gel electrophoresis of amplified DNA showing an $1100 \mathrm{bp}$ PCR fragment of $H$. saurida from both spores and EK-1 infected cells by primers HG4F and HG4R. Lanes: M: DNA ladder (100 bp, Invitrogen); 1 : $H$. saurida spores; 2: EK-1 cells infected with $H$. saurida; 3: control EK-1 cells; 4: negative control; 5: nontemplate control

\section{DISCUSSION}

Cellular and molecular studies of the microsporidian Heterosporis saurida have been hampered due to the lack of cell culture systems for this pathogen. Molecular and ultra-structural studies of $H$. saurida have been limited to in vivo and gene sequence analyses (Peyghan et al. 2009, Al-Quraishy et al. 2012). A cell culture model will offer a valuable means to explore molecular and immunological events, which helps in the development of effective therapeutic agents. Ideally, $H$. saurida would be cultured in a lizardfish cell line, but such a cell line has not yet been developed (Kumar et al. 2013). Although efforts have been made, e.g. by Kumar et al. (2013), lizardfish microsporidia have not been cultured successfully in other fish cell lines prior to this study. Herein, we investigated the capacity of eel kidney EK-1 cells to propagate $H$. saurida. We found that EK-1 cells supported development of $H$. saurida in vitro, thereby providing a fish cell culture model that enables further studies of the pathogen at the cellular level.

Currently, in vitro culturing of fish microsporidia using fish cell lines has not shared the success attained with other in vitro systems (Monaghan et al. 2009). Although cell lines from many fish are available, failure to culture microsporidia is probably due to a lack of specific differentiated cell and tissue types from fish (Monaghan et al. 2009). A variety of trials have been undertaken in this area of research. Short-term, primary cultures have been used to study the phagocytic and respiratory burst capabilities of phagocytes in response to fish microsporidia, and relatively long-term primary culture of salmonid leukocytes has been used to culture Nucleospora salmonis (Wongtavatchai et al. 1994, 1995, Desportes-Livage et al. 1996). Different fish cell lines were tested for their capacity to support the growth of fish microsporidia. The chinook salmon embryo cell line CHSE214 supported the growth of spores of Glugea sp. initially, but development stopped after $48 \mathrm{~h}$ (Lores et al. 2003). Pseudoloma neurophilia spores were collected from infected zebrafish Danio rerio and inoculated onto cultures of channel catfish ovary (CCO), zebrafish caudal fin fibroblast (SJD1), epithelioma papulosum cyprini (EPC), and fathead minnow epithelial (FHM) cell lines, which were then incubated at $28^{\circ} \mathrm{C}$. Aggregates of 8 or more spores per cell were observed but further development did not occur (Watral et al. 2007). The most promising in vitro fish microsporidia system utilizes the eel Anguilla japonica epithelial cell line (EP-1). This line was developed from infected tissues of eel elvers and can be infected with Pleistophora anguillarum (now Heterosporis anguillarum) (Kou et al. 1995, Lom et al. 2000, Monaghan et al. 2009).

Kumar et al. (2013) demonstrated an in vitro culture model for Heterosporis saurida in the mammalian cell line RK-13. Our findings suggest that mammals may act as a reservoir or incidental hosts of fish microsporidia, and that the fish microsporidia could be transmitted from fish to mammals, which further demonstrates the low host specificity in cell culture. However, the relationships between human and fish microsporidia require further investigations, which would benefit greatly from in vitro microsporidia cell culture systems to facilitate molecular and immunological studies (Didier et al. 1994, 1996, Deplazes et al. 1996, Hollister et al. 1996, Croppo et al. 1997, Didier 1997, Mathis et al. 1997, Franzen \& Müller 2001, del Aguila et al. 2001). In addition, chemotherapy testing and development for microsporidiosis would be facilitated by the establishment of such cell culture models (Didier 1997).

Ultrastructural examination of EK-1 infected cells showed that the structure of Heterosporis saurida was similar to the parasite in naturally infected lizardfish (Kumar et al. 2013). Except for the anterior end where the central zone of the anchoring disc contacted the wall, the spore wall was thick and consisted of an electron-lucent endospore and a thin electron-dense exospore (Fig. 2B) (Al-Quraishy et al. 2012). All developmental stages of $H$. saurida were observed in the EK-1 cells. Additionally, H. saurida spores were 
detected in EK-1 cells using anti-microsporidia polyclonal antibodies. The identity of the microsporidian spores was confirmed by PCR amplification and sequencing of the amplicons.

In this study, we have introduced a system for in vitro growth of Heterosporis saurida that allows research on this pathogen for the first time in a fish cell line, thereby expanding the fish cell line panel available for in vitro cultivation of microsporidia. Investigating cellular and molecular factors determining the interactions between $H$. saurida and fish cells on a cellular level will now be possible. Our cell culture model provides a cellular tool for analyzing this pathogen that allows rapid development of, and increase in, molecular knowledge on this fish pathogen, eventually facilitating the development of novel treatment methods.

Acknowledgements. We thank O. Haenen, National Reference Laboratory of Fish and Shellfish Diseases of the Netherlands, M. Glösmann (VetCORE) for providing help taking the confocal images, and M. W. Stock for technical assistance. This work was funded by King Saud University, National Program for Science and Technology (11-BIO1899-02).

\section{LITERATURE CITED}

Al-Quraishy S, Abdel-Baki AS, Al-Qahtani H, Dkhil M, Casal G, Azevedo C (2012) A new microsporidian parasite, Heterosporis saurida n. sp. (Microsporidia) infecting the lizardfish, Saurida undosquamis from the Arabian Gulf, Saudi Arabia: ultrastructure and phylogeny. Parasitology 139:454-462

> Breitenmoser AC, Mathis A, Burgi E, Weber R, Deplazes P (1999) High prevalence of Enterocytozoon bieneusi in swine with four genotypes that differ from those identified in humans. Parasitology 118:447-453

Chen SN, Ueno Y, Kou GH (1982) A cell line derived from Japanese eel (Anguilla japonica) kidney. Proc Natl Sci Counc Repub China B 6:93-100

> Coyle CM, Weiss LM, Rhodes LV III, Cali A and others (2004) Fatal myositis due to the microsporidian Brachiola algerae, a mosquito pathogen. N Engl J Med 351:42-47

Croppo GP, Visvesvara GS, Leitch GJ, Wallace S, De Groote MA (1997) Western blot and immunofluorescence analysis of a human isolate of Encephalitozoon cuniculi established in culture from the urine of a patient with AIDS. J Parasitol 83:66-69

> del Aguila C, Moura H, Fenoy S, Navajas R and others (2001) In vitro culture, ultrastructure, antigenic, and molecular characterization of Encephalitozoon cuniculi isolated from urine and sputum Samples from a Spanish patient with AIDS. J Clin Microbiol 39:1105-1108

> Deplazes P, Mathis A, Baumgartner R, Tanner I, Weber R (1996) Immunologic and molecular characteristics of Encephalitozoon-like microsporidia isolated from humans and rabbits indicate that Encephalitozoon cuniculi is a zoonotic parasite. Clin Infect Dis 22:557-559
Desportes-Livage I, Chilmonczyk S, Hedrick R, Ombrouck C, Monge D, Maiga I, Gentilini M (1996) Comparative development of two microsporidian species: Enterocytozoon bieneusi and Enterocytozoon salmonis, reported in AIDS patients and salmonid fish, respectively. J Eukaryot Microbiol 43:49-60

Didier ES (1997) Effects of albendazole, fumagillin, and TNP470 on microsporidial replication in vitro. Antimicrob Agents Chemother 41:1541-1546

$>$ Didier ES (2005) Microsporidiosis: an emerging and opportunistic infection in humans and animals. Acta Trop 94: $61-76$

> Didier ES, Varner PW, Didier PJ, Aldras AM and others (1994) Experimental microsporidiosis in immunocompetent and immunodeficient mice and monkeys. Folia Parasitol 41:1-11

Didier ES, Visvesvara GS, Baker MD, Rogers LB, Bertucci DC, DeGrotte MA, Vossbrinck CR (1996) A microsporidian isolated from an AIDS patient corresponds to Encephalitozoon cuniculi III, originally isolated from domestic dogs. J Clin Microbiol 34:2835-2837

> Franzen C, Müller A (2001) Microsporidiosis: human diseases and diagnosis. Microbes Infect 3:389-400

Gatehouse HS, Malone LA (1998) The ribosomal RNA gene region of Nosema apis (Microspora): DNA sequence for small and large subunit rRNA genes and evidence of a large tandem repeat unit size. J Invertebr Pathol 71: 97-105

Hirt RP, Logsdon JM, Healy B, Dorey MW, Doolittle WF, Embley TM (1999) Microsporidia are related to Fungi: evidence from the largest subunit of RNA polymerase II and other proteins. Proc Natl Acad Sci USA 96: 580-585

> Hollister WS, Canning EU, Anderson CL (1996) Identification of microsporidia causing human disease. J Eukaryot Microbiol 43:104S-105S

Hoshina T (1951) On a new microsporidan, Pleistophora anguillarum n. sp. from the muscle of the eel, Anguilla japonica. J Tokyo Univ Fish 38:35-46

> Keeling PJ, Fast NM (2002) Microsporidia: biology and evolution of highly reduced intracellular parasites. Annu Rev Microbiol 56:93-116

> Keeling PJ, Luker MA, Palmer JD (2000) Evidence from beta-tubulin phylogeny that microsporidia evolved from within the Fungi. Mol Biol Evol 17:23-31

Kou GH, Wang CH, Hung HW, Jang YS, Chou CM, Lo CF (1995) A cell line (EP-1 cell line) derived from 'Beko disease' affected Japanese eel elver (Anguilla japonica) persistently infected with Pleistophora anguillarum. Aquaculture 132:161-173

> Kumar G, Saleh M, Abdel-Baki AA, Al-Quraishy S, ElMatbouli M (2013) In vitro cultivation model for Heterosporis saurida (Microsporidia) isolated from lizardfish, Saurida undosquamis (Richardson). J Fish Dis doi:10.1111/ jfd.12123

Lom J, Dykova I (1992) Protozoan parasites of fishes. Elsevier, Amsterdam

> Lom J, Nilsen F (2003) Fish microsporidia: fine structural diversity and phylogeny. Int J Parasitol 33:107-127

> Lom J, Dykova I, Korting W, Klinger H (1989) Heterosporis schuberti n. sp., a new microsporidian parasite of aquarium fish. Eur J Protistol 25:129-135

> Lom J, Dykova I, Tonguthai K, Chinabut S (1993) Muscle infection due to Heterosporis sp. in Siamese fighting fish, Betta splendens Regan. J Fish Dis 16:513-516 
Lom J, Dyková I, Wang CH, Lo CF, Kou GH (2000) Ultrastructural justification for the transfer of Pleistophora anguillarum Hoshina, 1959 to the genus Heterosporis Schubert, 1969. Dis Aquat Org 43:225-231

Lores B, Rosales MJ, Mascaro C, Osuna A (2003) In vitro culture of Glugea sp. Vet Parasitol 112:185-196

Mathis A, Michel M, Kuster H, Müller C, Weber R, Deplazes P (1997) Two Encephalitozoon cuniculi strains of human origin are infectious to rabbits. Parasitology 114:29-35

Mathis A, Breitenmoser AC, Deplazes P (1999) Detection of new Enterocytozoon genotypes in faecal samples of farm dogs and a cat. Parasite 6:189-193

Michel C, Maurand J, Loubès C, Chilmonczyk S, de Kinkelin $\mathrm{P}$ (1989) Heterosporis finki, a microsporidian parasite of the angel fish Pterophyllum scalare: pathology and ultrastructure. Dis Aquat Org 7:103-109

Miller PE (2009) Diagnosis, prevalence, and prevention of the spread of the parasite Heterosporis sp. (Microsporida: Pleistophoridae) in yellow perch (Perca flavescens) and other freshwater fish in northern Minnesota, Wisconsin, and in Lake Ontario. MSc thesis, University of Wisconsin La Crosse, WI

Monaghan SR, Kent ML, Watral VG, Kaufman RJ, Lee LEJ, Bols NC (2009) Animal cell cultures in microsporidial research: their general roles and their specific use for fish microsporidia. In Vitro Cell Dev Biol Anim 45:135-147

Nageli K (1857) Über die neue Krankheit der Seidenraupe und verwandte Organismen. Bot Z 15:760-761

Pasteur L (1870) Étude sur la maladie des vers a soie: moyen pratique assuré de la combattre et d'en prévenir le retour. Imprimeur-Libraire, Paris

Peyghan R, Nabavi L, Jamshidi K, Akbari S (2009) Microsporidian infection in lizardfish, Saurida undosquamis of

Editorial responsibility: Dieter Steinhagen,

Hannover, Germany
Persian Gulf. Iran J Vet Res 10:180-185

Rinder H, Thomschke A, Dengjel B, Gothe R, Loscher T, Zahler M (2000) Close genotypic relationship between Enterocytozoon bieneusi from humans and pigs and first detection in cattle. J Parasitol 86:185-188

Sanders JL, Watral V, Kent ML (2012) Microsporidiosis in zebrafish research facilities. ILAR J 53:106-113

Schmahl G, Benini J (1998) Treatment of fish parasites. 11. Effects of different benzimidazole derivatives (albendazole, mebendazole, fenbendazole) on Glugea anomala, Moniez, 1887 (Microsporidia): ultrastructural aspects and efficacy studies. Parasitol Res 84:41-49

Sutherland D, Marcquenski S, Marcino J, Lom J and others (2000) Heterosporis sp. (Microspora: Glugeidae): a new parasite from Perca flavescens in Wisconsin and Minnesota. In: Proc 62nd Midwest Fish \& Wildlife Conference Abstracts, Minneapolis, MN, December 3-6, p 231-232

Visvesvara GS, Garcia LS (2002) Culture of protozoan parasites. Clin Microbiol Rev 15:327-328

Watral VG, Kauffman RB, Kent ML (2007) In vitro culture of Pseudoloma neurophilia, a common microsporidian of zebrafish (Danio rerio). J Eukaryot Microbiol 54:55S

Wittner M (1999) Historic perspective on the microsporidia: expanding horizons. In: Wittner M, Weiss LM (eds) The microsporidia and microsporidiosis. American Society of Microbiologists, Washington, DC, p 1-6

> Wongtavatchai J, Conrad PA, Hedrick RP (1994) In vitro cultivation of the microsporidian: Enterocytozoon salmonis using a newly developed medium for salmonid lymphocytes. J Tissue Cult Methods 16:125-131

> Wongtavatchai J, Conrad PA, Hedrick RP (1995) In vitro characteristics of the microsporidian: Enterocytozoon salmonis. J Eukaryot Microbiol 42:401-405

Submitted: July 4, 2013; Accepted: October 22, 2013

Proofs received from author(s): January 10, 2014 